\title{
Review of the Under One Umbrella Conference (Discover Connect Achieve) Manchester 2-3 July 2013
}

Jane Mansfield

\begin{abstract}
This article provides personal reflections on CILIP's Under One Umbrella Conference. The conference themes and keynote presentation are described and highlights are summarised. The article also describes the unconference elements (Unbrella), the Libraries Change Lives Award and the closing speech by CILIP President Phil Bradley.
\end{abstract}

\section{Introduction}

The Umbrella conference is a good way of staying up to date with developments in UK information management and it does have the capability to be a showcase for best practise in our profession. It is good to hear from other areas and I was delighted to read that Umbrella received an 'overwhelming' number of submissions in response to their call for papers.

The four main themes this year were:

- Future Skill and Future Roles which focused on what society will need from our profession.

- Information to Best Support Society which covered Information and digital literacy.

- Beyond Information Matters. This theme looked at the frontiers of knowledge and Information Management.

- Partnerships for Progress. This strand presented sessions on community engagement.

The Keynote, by Roly Keating Chief Executive of the British Library, celebrated the $40^{\text {th }}$ anniversary of the British Library. He discussed some of their bigger projects, including the partnership with Google which has brought about the

\section{Author}

Jane Mansfield is a Researcher Support Training Officer for PhD students in the Faculties of Business, Law, Arts \& Humanities.

Email: J.Mansfield@adm.leeds.ac.uk

Received 14 July 2013

Accepted 13 September 2013 
digitisation of around 250,000 books. The scale of the British Library's holdings is indicated by the fact that only $1 \%$ of their historical materials have been digitised. He also mentioned their partnership with BrightSolid which is digitising their newspaper holdings. He was positive about working with libraries across Britain, citing cities such as Manchester and Leeds.

\section{Future skills and future roles}

The first group of sessions in the Future Skills strand included Jo Alcock and Niamh Tumelty's discussion: 23 Things for professional development and its mapping against CILIP's PKSB (Professional Knowledge and Skills Base). Professional development is a topic that touches all of us and would definitely have benefited from being given a longer slot. This was one of my main impressions from Umbrella. The Spotlight Sessions were far too rushed and felt like brief summaries where a longer discussion would have been more valuable: it was like reading abstracts when you were hoping for articles. Many of these sessions ended up being 10 minute slots, because of the process of people filing into the rooms and searching for spare seats. Strong chairing of the sessions really helped and I applaud all the chairs for ushering participants towards seats, or directing them to sit on the floors. Those chairing also invariably kept everyone to time. Personally, I felt that the last session in the first Future Skills Spotlight session, delivered by a consultant from Sue Hill, could have happily been dropped. This would have given the 23 Things and a session about \#uklibchat a longer running time. Ka-Ming Pang's outline of \#uklibchat was full of energy and interest and she would be a good choice to deliver a talk at other conferences.

Debate sessions included Shay Moradi's discussion of gamification which mentioned Huddersfield University Libraries. Ben Lewis presented a section from his documentary on Google. His film looks at Google's trawl round the world to copy the world's rare (out of copyright) books. Google is not paying to copy all these rare items, but also Google is not being paid. The conundrum is that perhaps no other body would be willing and able to carry out such a massive project. Lewis raised the issue that Google will soon have access to 'all the world's information' and that this is probably not a good thing. This was raised as a Government and international issue rather than just being of concern to those in the information professions.

\section{Beyond information matters}

Sessions from the Beyond Information Matters strand included a witty review of technological progress from Brian Kelly and Simon Barron's discussion of the Cyborg librarian. Again these sessions were very interesting but felt short and sometimes rushed. Their presentations give an indication of their style and thoughts, and are worth a look. Most of the conference presentations are available on the CILIP site (CILIP, 2013a).

One of the highlights of the conference was Victoria Treadway and Dr Girendra Sadera's presentation of their work in an NHS critical care team. Victoria works alongside the intensive care team, providing fast searches for clinical guidelines and providing other information as required. She is an inspiration to other 
information specialists and was described as "a librarian with specific skills, or superpowers if you like".

Other sessions which may be of interest include Ruth Carlyle's session on Information Prescriptions. She works for MacMillan Cancer Support and showed how users can access packages of information for their illnesses. This seems such a great idea and can be seen at NHS Choices ([2013]). However, some of the information areas seem patchy, and the project might benefit from crowd-sourcing to highlight the most reliable and up-to-date sources of information for each illness. At the moment a Google search would often find you the same or more information.

\section{Unbrella, libraries changing lives and the cost of illiteracy}

There were many more sessions and activities which I hope will be mentioned in other reviews. I would just include here the Unbrella activities at Umbrella. The New Professionals group along with Library Camp delivered Unbrella events including a Heaven and Hell tombola, Human Bingo, breakfast meetings (what an awful thought) and pub quizzes. They also ran some post-session debates to encourage people to continue their discussions. Considering how rushed the main sessions were, I think many people would have been interested in a forum to continue their discussions. The Unbrella sessions were described as:

unconferences which means the participants lead the agenda - in fact, there isn't an agenda until people make suggestions for what they'd like to talk about at the start of the event.

It's a PowerPoint free zone and there are no keynotes speakers. Anyone can propose or lead or facilitate a session, just turn up and pitch your idea at the start of the event.

For more details see Library Camp (2013).

The Unbrella is a fabulous idea which could have been advertised more (even as footnotes) within the main programme. Although it was labelled as an Unconference, it was part of the Conference and you did need to have booked for Umbrella to attend the Unconference, so it could have been highlighted more in the main programme. Biddy Fisher, the conference director, does a great job of promoting new ideas within our profession, and as part of this she is an advocate for the New Professionals group.

CILIP's Libraries Change Lives Awards (CILIP, 2013b) were presented at the conference dinner by BBC's Fi Glover. The short list was a Dementia project from Kent Libraries, a Domestic Abuse initiative at Surrey Libraries and a Reading project at Kirklees, Yorkshire.

The conference's closing speech came from CILIP President Phil Bradley. This was a rousing presidential address focusing on the value of libraries and the threat of their diminishment. Phil stated that governments lose $£ 81$ bn a year through illiteracy. This is a shocking figure and I am not sure where the number comes from. He stated that a library is not a building and that the library doesn't exist without a librarian. He called for us to recognise that the library is a community service: That the value of the library lies in its role as a provider of social links, 
inspiration, education, creativity, mental health resources, holiday information and so on. He urged us to not fall in with the common practice of evaluating a library by its 'objects' - books, computers and catalogues, in the same way that a hospital is not evaluated as somewhere full of technical equipment and beds. The service is the main thing and should be what we emphasise. He again stressed that librarians should meet users where they are, which is often in cyberspace. One suggestion was that we could engage users to create resources, such as music videos, and then use these to advertise the libraries.

\section{Conclusion}

I really enjoyed hearing about different areas within the profession, on both a personal and professional level. Manchester University is a great venue and the conference is a good opportunity to share ideas across the many different areas of the information professions.

\section{References}

CILIP (2013a). Umbrella 2013 Presentations. URL: http://www.cilip.org.uk/umbrella2013/pages/presentations.aspx [accessed 02.10.13].

CILIP (2013b). CILIP Libraries Change Lives Awards. URL:

http://www.cilip.org.uk/about-us/medalsandawards/libraries-change-

lives/pages/lclawardintro.aspx [accessed 02.10.13].

Library Camp (2013). Umbrella's UNbrella. URL:

http://www.librarycamp.co.uk/2013/06/umbrellas-unbrella.html [accessed 02.10.13].

NHS Choices ([2013]). Information Prescription Services. URL: http://www.nhs.uk/ips [accessed 02.10.13].

\section{The Occasion}

Jane Mansfield attended CILIP Umbrella 2013 with the assistance of a sponsored place awarded by the Library and Information Research Group (LIRG).

\section{Open access and copyright}

Library and Information Research is an open access journal. A freely available copy of this paper may be downloaded from the journal's website: http://www.lirgjournal.org.uk/lir/ojs/index.php/lir/index

Copyright and associated moral rights in works published in Library and Information Research are retained by the author(s) but this paper may be used freely, with proper attribution, in educational and other non-commercial settings. 